\title{
Relationship Between Plant Density and Fruit and Seed Production in Muskmelon
}

\author{
Haim Nerson \\ Agricultural Research Organization, Department of Vegetable Crops, Newe Ya' ar Research Center, P.O.B. \\ 1021, Ramat Yishay 30095, Israel
}

\begin{abstract}
ADDITIONAL INDEX WORDs. Cucumis melo, germinability, marketable yield, seed yield index, yield quality
Abstract. Field experiments were conducted in 1996 and 1997 to examine the effects of plant density on yield and quality of fruit and seeds of muskmelons (Cucumis melo L.). Two open-pollinated cultivars, Noy Yizre'el (Ha'Ogen type) and TopMark (western U.S. shipper type), were grown at plant densities ranging from 0.5 to $16.0 \mathrm{plants} / \mathrm{m}^{2}$ under commercial conditions. The highest marketable fruit yields were achieved with plant densities of 2 to $4 \mathrm{plants} / \mathrm{m}^{2}$. In contrast, the highest seed yields were obtained at 8 to 12 plants $/ \mathrm{m}^{2}$. Seed yield index [seed yield (g)/fruit yield $(\mathrm{kg})$ ] was used as a parameter to define seed production efficiency. High seed yield was closely related to high value of the seed yield index. High seed yield indexes resulted from high plant densities (up to 12 plants $/ \mathrm{m}^{2}$ ), at which the crops produced many, but relatively small fruit. In all cases, the seed yield per fruit (seed number and seed size) increased with increasing fruit weight. However, the sum of the seed yield of two small fruit was always greater than the seed yield of one, double-sized fruit. There was a clear exception with extremely small fruit $(<500 \mathrm{~g})$, which produced both low seed yields and poor seed quality. A positive relationship was found between fruit size and seed size in both cultivars. Nevertheless, relatively small seeds ( 25 to $30 \mathrm{mg}$ ) extracted from relatively small fruit (500 to $1000 \mathrm{~g}$ ) showed the best performance in terms of germination and emergence percentages and rates, and in the vegetative development vigor of the seedlings.
\end{abstract}

Biological yields of field and horticultural crops can be increased by increasing the plant population within a wide range of densities (Bleasdale and Nelder, 1960). However, when the marketable yield of vegetable crops is considered, this range becomes much narrower. In cucurbit crops the effects of plant density on fruit yield and fruit quality are well documented. In watermelon the marketable yield was increased by decreasing the in-row spacing from 2.2 to $0.9 \mathrm{~m}$ (NeSmith, 1993), or by decreasing the space between rows from 4.5 to $1.5 \mathrm{~m}$ and that between the plants in the row from 2.4 to $0.6 \mathrm{~m}$ (Brinen et al., 1979). In summer squash, high plant densities of between 3 and 6 plants $/ \mathrm{m}^{2}$ produced the highest total and marketable yields in both sandy soil in Florida (Dweikat and Kostewicz, 1989) and heavy soil in Israel (Paris et al., 1986). In winter squash, the highest total yield was also achieved with a high plant density $\left(4.7\right.$ plants $\left./ \mathrm{m}^{2}\right)$, but a much lower density (1.1 plants/ $\mathrm{m}^{2}$ ) produced the highest marketable yield (Botwright et al., 1998). In cucumber, there is a large difference between the optimal density when the crop is grown for fresh consumption (Kasrawi, 1989) or for industrial processing (Wann, 1993). Many studies have revealed that 1 to 3 plants $/ \mathrm{m}^{2}$ is the optimal density for obtaining the highest return from a muskmelon fruit crop (Maynard and Scott, 1998; Nerson et al., 1984; Peirce and Peterson, 1961; Zahara, 1972).

In contrast to fruit yield, little attention has been given to the question of optimal plant density required for maximal seed yield and seed quality. It is logical to assume that a lot of data exists in the commercial seed industry, but only limited information is available in the literature. In cucurbit crops there is a general trend of using a higher plant density for optimal seed production than that used for fruit production. In watermelon grown for seed consumption(Nerson et al., 1994), maximum seed yield was achieved with 12,000 plants/ ha. In cucumber, a population of $\approx 50,000$ plants/ha was required to obtain the highest seed yield (Hammouda et al., 1982). In casaba melon grown in Israel for processing and seed production, a wide

Received for publication 7 Dec. 2001. Accepted for publication 10 May 2002. Contribution 143/2001 from the Agricultural Research Organization (ARO), Bet Dagan, Israel. I gratefully acknowledge the helpful advice of Michelle $\mathrm{H}$. Williams (HortResearch, Auckland, New Zealand) and of Harry S. Paris (Newe Ya'ar, Israel) in preparing the manuscript. range of densities was evaluated ( 2.2 to 15.2 plants $/ \mathrm{m}^{2}$ ) and it was found that 4.3 plants $/ \mathrm{m}^{2}$ produced the highest seed yield (Zemer et al., 1987).

The main purpose of the present study was to determine the influence of plant density on fruit and seed yields in two types of muskmelon. The quality of both fruit and seeds, and the relationships among fruit and seed yield and quality were also investigated.

\section{Materials and Methods}

FiELD EXPERIMENTS. Field experiments were conducted at the Newe Ya'ar Research Center (northern Israel) in two consecutive summer seasons. The crops were grown in one row in the center of raised beds $(0.3 \mathrm{~m}$ high and $2 \mathrm{~m}$ wide) under various in-row spacings. Cultural practices characteristic to the region were described previously (Nerson et al., 1989). Mature fruit (half to full slip) were harvested once a week for one month and were divided into five size groups: $<500,500$ to 1000,1000 to 1500,1500 to 2000 , and $>2000 \mathrm{~g}$. The total and the marketable fruit yields of each group were recorded and the seeds of each group were separately extracted. A fruit was considered marketable if it had no external defects and its weight was $>500 \mathrm{~g}$. A sample of five fruit per replication was taken in the second harvest to determine fruit quality, according to total soluble solids (TSS) values (Nerson et al., 1989). The total seed yield of each fruit-size group was established. The seeds of all the fruit were extracted, fermented for $48 \mathrm{~h}$, cleaned by tap water rinsing and dried in ambient air to $4 \%$ to $5 \%$ of moisture content. The ratio of seed yield $(\mathrm{g}) /$ fruit yield $(\mathrm{kg})$ was calculated for each fruit size group. This parameter was defined the seed yield index and described how many grams of seeds were produced by one $\mathrm{kg}$ of fruit. Five samples of 100 seeds per replication were taken to determine the 1000-seed weight. All the seed lots (75 in 1996 and 240 in 1997) were kept in a seed chamber $\left(10^{\circ} \mathrm{C}\right.$ and $\left.45 \% \mathrm{RH}\right)$ until they were used for quality evaluation.

In 1996, the cultivar used was Noy Yizre'el ('Ha'Ogen' muskmelon type). Three plant densities were examined: $0.5,2$, and 8 plants $/ \mathrm{m}^{2}$. The experimental design was a randomized block design with five replications, and each subplot area was $18 \mathrm{~m}^{2}$. The crop 
Table 1. Effects of plant density on fruit yield (total and marketable), yield components and total soluble solids (TSS) in 'Noy Yizre'el' and 'TopMark' muskmelons (summer 1997).

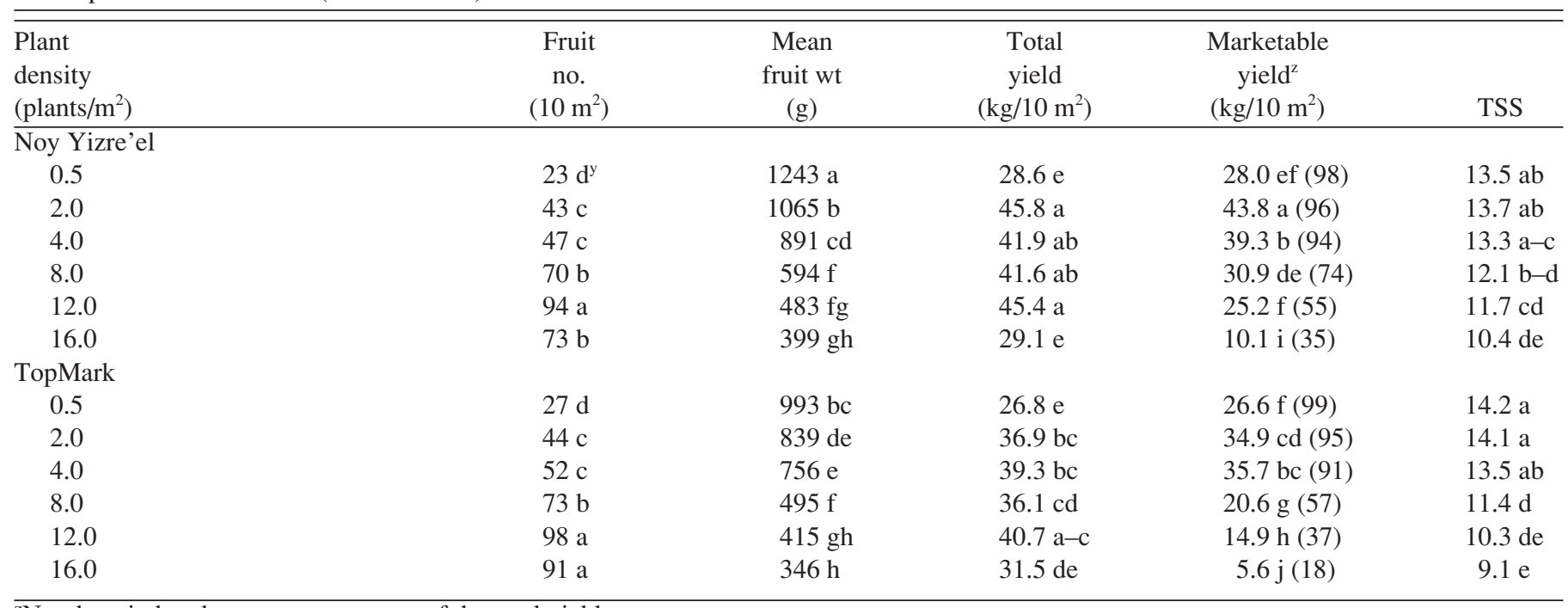

${ }^{\mathrm{z}}$ Numbers in brackets are percentages of the total yields.

'Mean separation in columns (among plant densities and cultivars) by Duncan's multiple range test, $P=0.05$.

was seeded on April 15,1996 and the seedlings were thinned to the final stands at the first-leaf stage. A portion of the results from this experiment was published in a previous paper (Nerson, 1999).

In 1997, two cultivars were used: Noy Yizre'el and TopMark (American western shipper type). Six plant densities were examined: $0.5,2,4,8,12$, and 16 plants $/ \mathrm{m}^{2}$. The experimental design was a randomized block design with four replications, and each subplot area was $16 \mathrm{~m}^{2}$. The crop was seeded on 17 Apr. 1997 and was thinned to the final stands at the first- to second-leaf stage.

GERMinATION TESTS. Standard germination tests were conducted on all seed lots collected from the two field experiments. The tests were carried out 6 months after seed harvest and were repeated after 1, 2, and 4 years of storage for the 1996 seed lots and after 1 and 3 years of storage for the 1997 seed lots. In each experiment four replications of 25 seeds were used per seed lot. The seeds were germinated in $9-\mathrm{cm}$ petri dishes on Whatman no. 3 filter paper saturated with $5 \mathrm{~mL}$ of distilled water. The seeds were incubated at $25^{\circ} \mathrm{C}$ in darkness and the germination percentages were recorded daily for $7 \mathrm{~d}$. A seed was considered germinated when the radicle reached $5 \mathrm{~mm}$ in length. Germination speed was calculated as the mean days to germination (MDG), as described previously (Nerson and Paris, 1988).

EMERGENCE AND SEEDLING DEVELOPMENT. The seed vigor of the 75 seed lots from the 1996 experiment (three plant densities $\times$ five fruit sizes $\times$ five replications) was examined in a greenhouse trial. The greenhouse night temperature never dropped below $16^{\circ} \mathrm{C}$ (heating) and the day temperature never exceeded $28^{\circ} \mathrm{C}$ (ventilation). Twenty-five seeds from each seed lot were seeded in $0.75-\mathrm{L}$ pots on 5 Mar. 1997. The pots were filled with a medium mix containing $40 \%$ organic compost, $40 \%$ tuff (granulated volcanic ash) and $20 \%$ vermiculite. Emergence percentages were recorded daily for $15 \mathrm{~d}$. One seedling per seed lot was sampled $8,15,22$, and $29 \mathrm{~d}$ past seeding to determine the effects of plant density and fruit size in the mother plants on the vegetative development (leaf number and dry weight, and stem length and dry weight) of the seedlings.

SeED SIZE AND GerminabiLITy. The same 75 seed lots as in the previous section were sorted according to individual seed weight (in milligrams) into five groups: 15 to 20,20 to 25,25 to 30,30 to 35 , and 35 to 40 . Four replications of 25 seeds per weight group from each seed lot were used for the standard germination test, incubated on 5 July 1997, to determine the effects of seed size on germination percentage and rate.

Germination, emergence and seedling development data of seeds extracted from the largest fruit size category $(>2000 \mathrm{~g}$ ) were not presented in the Results section since in many plots there were no fruit of this category and in many other plots only one to three fruit of this size were harvested.

Statistical anAlYsis. All data were subjected to a two- or threeway ANOVA. Germination and emergence percentages were arcsin transformed before analysis (Little, 1985). Means were separated in most cases by Duncan's multiple range test. Since no interactions were found between the effects of fruit weight and seed weight on germination, the data were pooled and only the means are presented. In this case, separation was given by LSD values.

Table 2. Effects of plant density on seed yield, mean seed weight and seed yield index in 'Noy Yizre'el' and 'TopMark' muskmelons (summer 1997).

\begin{tabular}{cccc}
\hline \hline $\begin{array}{l}\text { Plant } \\
\text { density } \\
\left(\text { plants } / \mathrm{m}^{2}\right)\end{array}$ & $\begin{array}{c}\text { Seed } \\
\text { yield } \\
\left(\mathrm{g} / 10 \mathrm{~m}^{2}\right)\end{array}$ & $\begin{array}{c}\text { Mean } \\
\text { seed wt } \\
(\mathrm{mg})\end{array}$ & $\begin{array}{c}\text { Seed } \\
\text { yield } \\
\text { index }\end{array}$ \\
\hline $\begin{array}{l}\text { Noy Yizre'el } \\
0.5\end{array}$ & $339 \mathrm{f}^{\mathrm{y}}$ & $32.8 \mathrm{a}$ & $11.9 \mathrm{f}$ \\
2.0 & $592 \mathrm{~b}-\mathrm{d}$ & $32.6 \mathrm{a}$ & $13.0 \mathrm{ef}$ \\
4.0 & $577 \mathrm{~cd}$ & $29.9 \mathrm{ab}$ & $13.7 \mathrm{~d}-\mathrm{f}$ \\
8.0 & $687 \mathrm{ab}$ & $27.9 \mathrm{~b}$ & $16.4 \mathrm{ab}$ \\
12.0 & $703 \mathrm{a}$ & $25.7 \mathrm{bc}$ & $15.6 \mathrm{a}-\mathrm{d}$ \\
16.0 & $500 \mathrm{de}$ & $25.4 \mathrm{bc}$ & $16.9 \mathrm{a}$ \\
TopMark & & & \\
0.5 & $330 \mathrm{f}$ & $22.9 \mathrm{~cd}$ & $12.3 \mathrm{f}$ \\
2.0 & $516 \mathrm{~d}$ & $22.7 \mathrm{~cd}$ & $13.9 \mathrm{c}-\mathrm{f}$ \\
4.0 & $578 \mathrm{~cd}$ & $23.2 \mathrm{~cd}$ & $14.7 \mathrm{~b}-\mathrm{e}$ \\
8.0 & $572 \mathrm{~cd}$ & $20.5 \mathrm{~d}$ & $15.9 \mathrm{a}-\mathrm{c}$ \\
12.0 & $634 \mathrm{a}-\mathrm{c}$ & $20.4 \mathrm{~d}$ & $15.9 \mathrm{a}-\mathrm{c}$ \\
16.0 & $421 \mathrm{ef}$ & $19.3 \mathrm{~d}$ & $13.3 \mathrm{ef}$ \\
\hline
\end{tabular}

${ }^{\mathrm{z}}$ Seed yield (g)/fruit yield (kg).

y Mean separation in columns (among plant densities and cultivars) by Duncan's multiple range test, $P=0.05$. 


\section{Results}

Fruit YIELD. Plant density had opposite effects on fruit yield components: increasing the plant density increased the fruit number per unit area but decreased the mean fruit weight (Table 1). This effect resulted in similar total fruit yields over a wide range of plant densities. In both 'Noy Yizre'el' and 'TopMark' the total fruit yield diminished only at the extreme densities $\left(0.5\right.$ and 16.0 plant $\left./ \mathrm{m}^{2}\right)$. However, plant density had a clear and significant effect on the marketable fruit yield: the highest marketable yield in both cultivars was obtained at two and four plants $/ \mathrm{m}^{2}$. At a lower density the total fruit yield set the limit and at higher densities an increasing proportion of small, noncommercial fruit decreased the marketable yield. The fruit quality, expressed in TSS contents, also decreased at the high plant densities.

SEED YIELD. The highest seed yields were achieved at plant densities of 8 to 12 and 4 to 12 plants $/ \mathrm{m}^{2}$ in 'Noy Yizre'el' and 'TopMark', respectively (Table 2). Seed yields significantly decreased at both the highest and the lower plant densities. Increasing plant density, significantly decreased the mean seed weight in 'Noy Yizre'el': the decrease in mean seed weight from the highest to the lowest density was $23 \%$. The same trend, although not significant, was observed in 'TopMark'. When the highest density was excluded, the two cultivars had similar seed yield index values. Generally, there was a positive relationship between the seed yield and the seed yield index.

FruIT SIZE, PLANT DENSITY AND SEED YIELD INDEX. The seed yield index (seed yield /fruit yield) was affected by fruit size in both cultivars (Table 3). The highest seed yield index values were obtained in fruit weighing $<1000$ g. In 'Noy Yizre'el', but not in 'TopMark', fruit weighing $<500 \mathrm{~g}$ tended to have lower seed yield indexes than those weighing 500 to $1000 \mathrm{~g}$. The seed yield index of fruit heavier than $1000 \mathrm{~g}$ tended to decrease linearly. Plant density also affected the seed yield index (Table 2): the seed yield index value increased as plant density increased up to 8 plants $/ \mathrm{m}^{2}$. In 'Noy Yizre'el' about the same value was maintained up to the highest density (16 plants $\left./ \mathrm{m}^{2}\right)$, whereas in 'TopMark' the seed yield index tended to decrease when the plant density exceeded 12 plants $/ \mathrm{m}^{2}$.

RELATIONSHIP BETWEEN FRUIT SIZE AND SEED YIELD. Fruit size, expressed as fresh weight, had significant effects on seed yield per fruit in both 'Noy Yizre'el' and 'TopMark' (Table 3): the seed yield increased with fruit size in both cultivars. The increased seed yield was due to almost equal increases in both the seed number per fruit and the mean seed weight. However, the seed yield increase was, in all cases, smaller than the increase in fruit size. For example, an increase in fruit size from 500 to $1000 \mathrm{~g}$ to 1500 to $2000 \mathrm{~g}$, resulted in seed yield increase of only $65 \%$ to $83 \%$.

Seed GerminabiLITy. The germination percentage of seeds extracted from small fruit $(<500 \mathrm{~g}$ in both years and also 500 to 1000 $\mathrm{g}$ in 1996) increased with increasing plant density (Table 4). This tendency was opposite in 'Noy Yizre'el' in the 1997 experiment, for seeds harvested from all fruit larger than $500 \mathrm{~g}$. Seeds of 'TopMark' had higher germinability than those of 'Noy Yizre'el'. This difference between cultivars was expressed in germination percentages (Table 4) and also in germination rates. The mean days to germination (MDG) was 2.52 and 3.24 for 'TopMark' and 'Noy Yizre'el', respectively (data not presented). Seeds from small $(<500 \mathrm{~g})$ or large $(>1500 \mathrm{~g})$ fruit tended to have lower germinability than seeds from intermediate fruit sizes (Table 4). Seeds of 'Noy Yizre'el' extracted from fruit weighing 500 to $1000 \mathrm{~g}$ had the highest germinability (percentage and rate) (Table 5). The lowest germinability was found in seeds from the largest fruit, while the two other fruit size groups $(<500$ and 1000 to $1500 \mathrm{~g})$ showed intermediate germinability. Small seeds of 'Noy Yizre'el' ( $<25 \mathrm{mg}$ ) had a lower germination percentage than larger seeds (Table 5).

SEedLings EMERGENCE AND DEVELOPMENT. Fruit size significantly affected emergence percentage and mean days to emergence of the seedlings (Table 6). Seeds extracted from the largest fruit (1500 to $2000 \mathrm{~g}$ ) had the lowest and the slowest emergence. Seeds from the smallest fruit $(<500 \mathrm{~g})$ also tended to have lower emergence percentages than those from medium-size fruit. Seedlings that developed from seeds extracted from fruit of different size catego-

Table 3. Effects of fruit weight on seed yield, seed yield components and seed yield index in 'Noy Yizre'el' and 'TopMark' muskmelons.

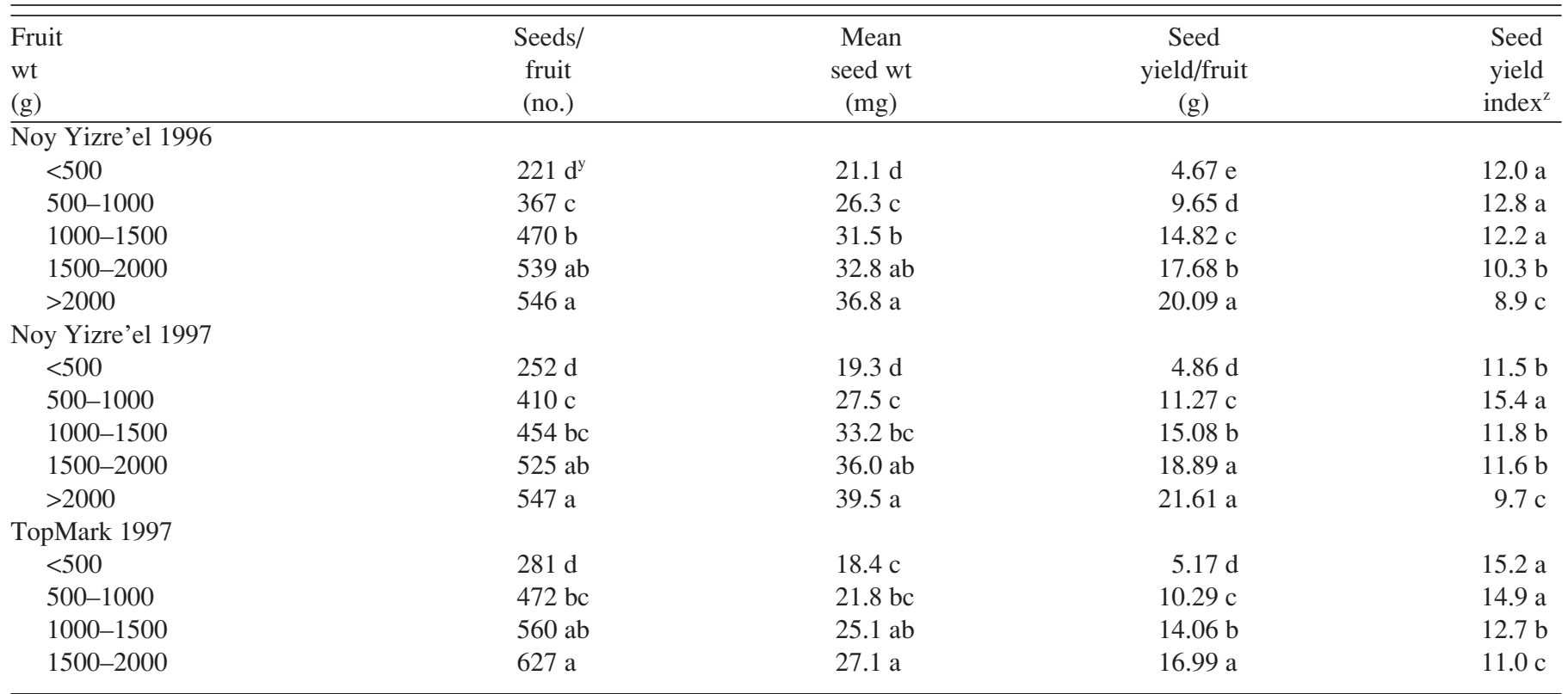

${ }^{\mathrm{z}}$ Seed yield $(\mathrm{g}) /$ fruit yield $(\mathrm{kg})$.

${ }^{y}$ Mean separation in columns (among fruit weights) by Duncan's multiple range test, $P=0.05$. Each year and each cultivar in the same year were analyzed separately. 
Table 4. Effects of plant density and fruit weight of the mother plants on the germination percentage ${ }^{\mathrm{z}}$ in 'Noy Yizre'el' and 'TopMark' muskmelons.

\begin{tabular}{|c|c|c|c|c|}
\hline \multirow{2}{*}{$\begin{array}{l}\text { Plant } \\
\text { density } \\
\left.\text { (plants } / \mathrm{m}^{2}\right)\end{array}$} & \multicolumn{4}{|c|}{ Fruit wt (g) } \\
\hline & $<500$ & $500-1000$ & $1000-1500$ & $1500-2000$ \\
\hline 0.5 & $41 \mathrm{~cd}^{\mathrm{y}}$ & $50 \mathrm{c}$ & $48 \mathrm{c}$ & $30 \mathrm{e}$ \\
\hline 2.0 & $41 \mathrm{~cd}$ & $73 \mathrm{a}$ & $65 \mathrm{~b}$ & $37 \mathrm{de}$ \\
\hline 8.0 & $75 \mathrm{a}$ & $75 \mathrm{a}$ & $49 \mathrm{c}$ & $44 \mathrm{~cd}$ \\
\hline 2.0 & 38 hi & $57 \mathrm{~cd}$ & $70 \mathrm{~b}$ & $51 \mathrm{~d}-\mathrm{f}$ \\
\hline 4.0 & $17 \mathrm{k}$ & $43 \mathrm{f}-\mathrm{i}$ & $54 \mathrm{de}$ & $47 \mathrm{~d}-\mathrm{g}$ \\
\hline 8.0 & $56 \mathrm{~cd}$ & $52 \mathrm{~d}-\mathrm{f}$ & $45 \mathrm{e}-\mathrm{h}$ & $24 \mathrm{j}$ \\
\hline 12.0 & $51 \mathrm{~d}-\mathrm{f}$ & $39 \mathrm{~g}-\mathrm{i}$ & $37 \mathrm{i}$ & $36 \mathrm{i}$ \\
\hline 16.0 & $50 \mathrm{~d}-\mathrm{f}$ & $50 \mathrm{~d}-\mathrm{f}$ & $23 \mathrm{j}$ & $--{ }^{x}$ \\
\hline 8.0 & $88 \mathrm{c}-\mathrm{e}$ & $96 a b$ & $89 \mathrm{c}-\mathrm{e}$ & --- \\
\hline 12.0 & $90 b-d$ & $96 \mathrm{ab}$ & 99 a & --- \\
\hline 16.0 & 80 ef & 81 ef & $100 \mathrm{a}$ & --- \\
\hline
\end{tabular}

${ }^{\mathrm{z}}$ Each number is the mean of four (1996) or three (1997) germination tests conducted 0.5 to 4.0 years after seed harvest.

y Mean separation in each year and cultivar by Duncan's multiple range test, $P=0.05$, after arcsin transformation.

${ }^{\mathrm{x}}$ No seeds available.

Table 5. Effects of fruit weight and seed weight on germination percentage and on germination rate in 'Noy Yizre'el' muskmelon (summer 1996).

\begin{tabular}{|c|c|c|}
\hline Treatment & Germination $(\%)$ & $\begin{array}{c}\text { Germination } \\
\text { rate } \\
(\mathrm{MDG})^{\mathrm{z}}\end{array}$ \\
\hline \multicolumn{3}{|l|}{ Fruit weight (g) } \\
\hline$<500$ & 51 & 3.0 \\
\hline $500-1000$ & 66 & 2.6 \\
\hline $1000-1500$ & 48 & 3.2 \\
\hline 1500-2000 & 29 & 3.7 \\
\hline \multicolumn{3}{|l|}{ Seed weight (mg) } \\
\hline $15-20$ & 30 & 3.0 \\
\hline $20-25$ & 44 & 2.9 \\
\hline $25-30$ & 54 & 3.2 \\
\hline $30-35$ & 57 & 3.3 \\
\hline $35-40$ & 57 & 3.3 \\
\hline $\mathrm{LSD}_{\text {fruit weight }} P=0.05$ & 7.3 & 0.45 \\
\hline $\mathrm{LSD}_{\text {seed weight }} P=0.05$ & 8.7 & NS \\
\hline
\end{tabular}

${ }^{\mathrm{z}}$ Mean days to germination.

ries had the same number of leaves 29 days after seeding (Table 6). However, the stem length and the dry weight of all the organs of the shoot were smaller in seedlings that developed from seeds of the smallest fruit than in those that developed from seeds of larger fruit.

\section{Discussion}

One important practical conclusion arising from the present study on muskmelon is that optimal production of fruit and of seeds requires different plant densities. Fruit yield per unit area is the simple product of fruit number per unit area and the mean fruit weight. On the other hand, seed yield comprises three components: fruit number per unit area, seed number per fruit and mean seed weight. Because increasing plant density increased fruit number but decreased fruit weight there was a wide range of plant densities with the same total fruit yields (Table 1). However, as muskmelon fruit is consumed as a dessert, its quality (size, sweetness, texture) is extremely important. When quality characteristics are considered, the marketable yield (which may differ in different markets) is the main parameter of fruit yield production. In the present study 2 to 4 plants $/ \mathrm{m}^{2}$ was the optimal density for high-quality fruit production; which is in agreement with earlier findings (Peirce and Peterson, 1961; Nerson et al., 1989). The highest seed yield, in contrast to fruit yield, was obtained at higher plant densities: 8 to 12 plants $/ \mathrm{m}^{2}$ for 'Noy Yizre'el' and 4 to 12 plants/m² for 'TopMark' in the 1997 experiment (Table 2). The limited data from the 1996 experiment had shown a similar trend and were published previously (Nerson, 1999). Increasing the plant density decreased the mean fruit weight in both cultivars (Table 1), the mean seed weight in 'Noy Yizre'el' (Table 2), and there was a similar tendency in 'TopMark'. This relationship between fruit and seed size in muskmelons is different from that observed in watermelon [Citrullus lanatus (Thunb.) Matsum. \& Nakai] in which fruit of a large range of sizes do not differ in their seed size (Edelstein and Nerson, 2002 in press). In the major cucurbit crops, two contrasting paths have developed over the course of evolution and domestication, concerning the relationship, or lack of it, between fruit and seed sizes. One path, on which seed size is affected by fruit size, has been followed by melon. The other path, on which seed size is hardly or not at all affected by fruit size, has been followed by watermelon. In melon, the mesocarp tissue is the fruit flesh and is the part which is consumed by humans. Under domestication, the mesocarp has been selected for increased size and thickness at the expense of the endocarp, the soft, stringy placental tissue, and the small volume of placental tissue may be a limiting factor for seed size. On the other hand, in watermelon, the placental tissue is the part consumed, therefore the aim of selection has been a large endocarp volume which places no restriction on seed size.

The present study has demonstrated that the seed yield index is 
Table 6. Effects of fruit weight on seedling emergence and on seedling vegetative development in 'Noy Yizre'el' muskmelon (summer 1996).

Seedling vegetative development ${ }^{2}$

\begin{tabular}{|c|c|c|c|c|c|c|c|c|c|}
\hline \multirow{3}{*}{$\begin{array}{l}\text { Fruit } \\
\text { wt } \\
\text { (g) } \\
\end{array}$} & \multirow{2}{*}{\multicolumn{2}{|c|}{$\begin{array}{l}\text { Seedling } \\
\text { emergence }\end{array}$}} & \multicolumn{3}{|c|}{ Stem } & & & & \\
\hline & & & \multirow{2}{*}{$\begin{array}{c}\text { Leaves } \\
\text { (no.) }\end{array}$} & \multirow{2}{*}{$\begin{array}{l}\text { Length } \\
(\mathrm{cm})\end{array}$} & \multirow{2}{*}{$\begin{array}{c}\text { Dry wt } \\
(\mathrm{mg})\end{array}$} & \multicolumn{4}{|c|}{ Leaf dry wt (mg) } \\
\hline & $\%^{y}$ & $\mathrm{MDE}^{\mathrm{x}}$ & & & & Cotyledons & $1^{\text {st }}$ & $2^{\text {nd }}$ & $3^{\text {rd }}$ \\
\hline $500-1000$ & $68 \mathrm{a}$ & $5.7 \mathrm{~b}$ & $2.9 \mathrm{a}$ & $8.6 \mathrm{a}$ & $151 \mathrm{a}$ & $63 \mathrm{a}$ & $136 \mathrm{a}$ & $178 \mathrm{a}$ & $112 \mathrm{a}$ \\
\hline $1000-1500$ & $57 \mathrm{ab}$ & $6.5 \mathrm{~b}$ & $3.1 \mathrm{a}$ & $8.6 \mathrm{a}$ & $158 \mathrm{a}$ & $63 a$ & $138 \mathrm{a}$ & $188 \mathrm{a}$ & $130 \mathrm{a}$ \\
\hline 1500-2000 & $40 \mathrm{c}$ & $7.5 \mathrm{a}$ & $3.0 \mathrm{a}$ & $8.2 \mathrm{ab}$ & $144 \mathrm{a}$ & $64 \mathrm{a}$ & $137 \mathrm{a}$ & $177 \mathrm{a}$ & $112 \mathrm{a}$ \\
\hline
\end{tabular}

${ }^{\mathrm{z}}$ Data collected 29 days after seeding.

y Data collected 15 days after seeding.

${ }^{\mathrm{x}}$ Mean days to emergence.

wSeparation in columns (among fruit weights) by Duncan's multiple range test, $P=0.05$.

a reliable indicator of seed production efficiency. There is a clear positive association between these two parameters, and a high efficiency is associated with high seed yield indexes. A positive relationship between seed yield and seed yield index, as affected by plant density, was obtained in the present study for both muskmelon cultivars (Table 2 and Nerson, 1999) and was found previously in watermelon (Nerson et al., 1994). High seed yield and high seed yield index values were achieved in muskmelon by using relatively high plant densities (Table 2). The only exception to this was the diminution of seed yields in both cultivars and the decrease in the seed yield index in 'TopMark' at the highest plant density. This may be explained by the fact that with a very high plant density, in addition to increased competition among plants, the dense leaf canopy is likely to impair efficient pollination by bees.

A high seed yield index was also associated with small fruit (Table 3), and high seed yields were obtained at high plant densities which led to the production of many but relatively small fruit. This was true in spite of the observation that both the number of seeds per fruit and the mean seed weight increased with increasing fruit size (Table 3). In all cases, as the fruit weight increased, the increase in seed yield per fruit was proportionally less than the increase in fruit size. For example, the seed yield from two fruit in the 500 to 1000 g category was higher than that from one fruit in the 1500 to 2000 g category. Thus, in order to produce high seed yields in muskmelon, one has to use agrotechnical practices which enhance the production of many small fruit.

The germination percentages of 'Noy Yizre'el' seeds obtained in both experiments were quite low and were unacceptable in commercial terms. This, cultivar dependent trait is characteristic of genotypes with a high parthenocarpic fruit set tendency (Nerson, data unpublished), and does not appear in 'TopMark'. In contrast to commercial seed production, the present seed lots were not sorted and cleaned prior to determining quality differences among the treatments. In the present study the highest germination percentages were obtained in the three medium-size seed groups ( 25 to $40 \mathrm{mg}$ ). Neither very small (15 to $20 \mathrm{mg}$ ) nor very large (>40 mg) seeds of the cultivar 'Noy Yizre'el' germinated well (Table 5 and unpresented data). Many reports, especially in field crops, show the advantages of large seeds over small ones (de Marco, 1990; Kolawole and Kang, 1997; Naylor, 1993), but there are contradictory data as well (Saranga et al., 1998). The results presented here indicate that in muskmelons there was no significant effect of the seed size on germination as long as they were not extremely small or extremely large.

A consistent effect of fruit size on seed germinability (Table 5) and seedling development (Table 6) was observed with the 1996 seed lots. Seeds extracted from fruit weighing 500 to $1000 \mathrm{~g}$ had the highest germination percentage and rate and the highest emergence percentage and rate, and their seedlings had the same vegetative development rate as those developed from seeds of larger fruit. Thus, a high plant density, produced high seed yield, mainly through the production of relatively small fruit, put no risk on the seed quality. Only very small fruit $(<500 \mathrm{~g})$, which in many cases developed late and were immature, yielded poor-quality seeds.

\section{Literature Cited}

Bleasdale, J.K.A. and J.A. Nelder. 1960. Plant population and crop yield. Nature 188:342. Botwright, T., N. Mendham, and B. Chung. 1998. Effect of density on growth, development, yield and quality of kabocha (Cucurbita maxima). Austral. J. Expt. Agr. 38:195-200.

Brinen, G.H., S.J. Locasio, and G.W. Elmstom. 1979. Plant and row spacing, mulch and fertilizer rate effects on watermelon production. J. Amer. Soc. Hort. Sci. 104:724-726.

de Marco, D.G. 1990. Effect of seed weight, and seed phosphorus and nitrogen concentrations on the early growth of wheat seedlings. Austral. J. Expt. Agr. 30:545-549.

Dweikat, I.M. and S.R. Kostewicz. 1989. Row arrangement, plant spacing, and nitrogen rate effects on zucchini squash yield. HortScience 24:86-88.

Edelstein, M. and H. Nerson. 2002. Effects of genotype and plant density on watermelon grown for seed consumption. HortScience (in press).

Hammouda, A., M. Elsherbini, and M.Z. Farrag. 1982. Effect of some treatments on cucumber seed production. Agr. Res. Rev. 60:227-234.

Kasrawi, M. 1989. Response of cucumbers grown in plastic greenhouses to plant density and row arrangement. J. Hort. Sci. 64:573-579.

Kolawole, G.O. and B.T. Kang. 1997. Effect of seed size and phosphorus fertilization on growth of selected legumes. Commun. Soil Sci. Plant Anal. 28:1223-1235.

Little, T.M. 1985. Analysis of percentage and rating scale data. HortScience 20:642-644

Maynard, E.T. and W.D. Scott. 1998. Plant spacing affects yield of 'Superstar' muskmelon. HortScience 33:52-54.

Naylor, R.E.L. 1993. The effect of parent plant nutrition on seed size, viability and vigour and on germination of wheat and triticale at different temperatures. Ann. Appl. Biol. 123:379390 .

Nerson, H. 1999. Effects of population density on fruit and seed production in muskmelon. Acta Hort. 492:65-70

Nerson, H. and H.S. Paris. 1988. Effects of fruit age, fermentation and storage on germination of cucurbit seeds. Scientia Hort. 35:15-26.

Nerson, H., Y. Burger, and R. Berdugo. 1994. High plant density and irrigation increase watermelon yield grown for seed consumption. Adv. Hort. Sci. 8:101-105.

Nerson, H., R. Cohen, M. Edelstein, and Y. Burger. 1989. Paclobutrazol—A plant growth retardant for increasing yield and fruit quality in muskmelon. J. Amer. Soc. Hort. Sci. 114:762-766.

Nerson, H., M. Edelstein, H.S. Paris, Z. Karchi, and A. Govers. 1984. Effects of population density and plant spacing on the vegetative growth, flowering and yield of cv. Galia muskmelon (Hebrew with English abstract). Hassadeh 64:698-702.

NeSmith, D.S. 1993. Plant spacing influences watermelon yield and yield components. HortScience 28:885-887.

Paris, H.S., H. Nerson, and Z. Karchi. 1986. Yield and yield quality of courgette as affected by plant density. J. Hort. Sci. 61:295-301.

Peirce, L.C. and L.E. Peterson. 1961. The response of muskmelons to spacing, seeding date and plant container. Proc. Amer. Soc. Hort. Sci. 77:432-439.

Saranga, Y., A. Levi, P. Horcicka, and S. Wolf. 1998. Large sunflower seeds are characterized by low embryo vigor. J. Amer. Soc. Hort. Sci. 123:470-474.

Wann, E.V. 1993. Cucumber yield response to plant density and spatial arrangement. J. Prod. Agr. 6:253-255.

Zahara, M. 1972. Effects of plant density on yield and quality of cantaloupes. Calif. Agr. 26:15.

Zemer, B., M. Levy, and A. Reis. 1987. Optimal spacing of melon (cv. Noy Amid) for maximal seed and fruit production (In Hebrew). Hassadeh 67:1332-1333, 1341. 